\title{
IMPROVING ENGLISH VOCABULARY MASTERY THROUGH WORD GAME
}

\author{
Siti Nuraeni ${ }^{1}$, Chrissandra Intan Lube ${ }^{2}$ \\ ${ }^{1}$ IKIP Siliwangi \\ ${ }^{2}$ IKIP Siliwangi \\ 1'medmohtea@gmail.com, ${ }^{2}$ chrissandra42@gmail.com
}

\begin{abstract}
Vocabulary is very important in learning English. To master four skills in English, we need mastery vocabulary first. So, the researchers use word game in the classroom to make students interest to learn vocabulary. The objective of this research is to know that the word game is effective to improve students' vocabulary or not, through word game strategy among seventh-grade students of SMP Muslimin Cililin in the academic year of 2018/2019. The method used in this research is quantitative technique and the pre-experimental as a research design. This research was conducted in one class. The population in this research is seventh-grade students of SMP Muslimin Cililin with the total number of the population are 273 students consisting of 7 classes, and the sample is class VII.C that consist of 30 students. The data were collected with the pretest and posttest as an instrument. The researchers conducted the tests before (pre-test) and after (post-test). After that the researchers gave students treatments consists of five meetings. The result showed that Sig. 0.000 and it was lower than 0.005 so, the null hypothesis was rejected and the alternative hypothesis was accepted. It means that teaching English vocabulary using a word game was effective to improve students' vocabulary at seventh-grade.
\end{abstract}

Keywords: Word Game, Students' Vocabulary Mastery

\section{INTRODUCTION}

Learning English is important for students in era globalization. So we need to enhance english skill in the world community. To master English, students should begin learning english with vocabularies. The vocabulary is an important thing in learning English, because without knowing vocabulary, there is nothing we can express in four language skill, namely listening, speaking, reading, and writing.

Vocabulary is very important language component in learning english. According to Murcia (2001: 285) in Parmawati states that vocabulary learning is central to language acquisition , whether the language is first, second or foreign. Thornbury (Parmawati 2018) holds that language comprehension and production will be hampered because of lack of vocabulary. Student can mastery listening, speaking, reading, and writing if they can be able mastery of many vocabularies. To enhance student's interest and motivation in vocabulary, the teacher need to create teaching strategy and method.

The students have to improve their vocabulary mastery, one of strategy to improve student's vocabulary is by using game. Game helps teachers to maximize each students' learning potential (S, Sugar \& K 2002). Sanhez, Morfin \& Campos (Sanchez 2007) points ou that games give the student an opportunity to use their language in a less formal situation. So the researcher chooses the game as learning strategy to improve student's vocabulary mastery.

Game is very appropriate to apply in teaching vocabulary. Huyen \& Nga (2003) as cited in Linse (2005) say that game in classroom can be one of effective strategies in teaching 
vocabulary. Harmer (Jeremy Harmer 2001) states that game can make learners to be more enthusiastic in learning vocabulary. It is in line with Cheng \& Su (2012, in Apsari 2018) that game-based learning can make learners become the center of learning, make the learning process easier, more interesting and effective.

In addition, Bonet (D 1992) also explains that by a variety of odd words, puzzlle and games can make learners motivate in learning vocabulary. The various of teaching method in learning process will make students more interest and can motivate student in learning english.

In the seventh grade of SMP Muslimin Cililin, many problems are faced by students in learning english, the students have lack of vocabulary, because students were not interested in learning english, they feel difficult to memorize vocabulary and the are difficult to pronuncation the words of english. So students do not have motivation in learning english.

Based on the problem above, the researchers use word game to improve students' vocabulary mastery. The aim of this research is to know that words game is effective to improve students' vocabulary mastery in the seventh grade of SMP Muslimin Cililin.

\section{METHOD}

This research explains to enhance English vocabulary mastery by using word game in the seventh grade at SMP Muslimin Cililin. The purpose of this research is to know that word game is effective to improve students' vocabulary or not. The researchers use the quantitative method,and the pre-experimental research design used in one class. According to Crowl (1996:10) as cited in Suryani (Suryani 2015), "quantitative method is used to examine questions that can be best answered by collecting and statistically analyzing data that are in numerical form". Sugiyono (2006:80) say that experimental research is a research which has the purpose to find the cause-effect relationship among the variables in controlled condition. The population in this research is seventh-grade students of SMP Muslimin Cililin with the total student of the population are 273 students consisting of 7 classes, and the sample is class VII.C that consist of 30 students. The data was collected by using pretest and posttest then the data were analysed by SPSS.

\section{RESULTS AND DISCUSSION}

\section{Results}

In this section the researchers used SPSS version 15.0 to answer whether word game is effective to improve students' vocabulary at the seventh-grade of SMP Muslimin Cililin, with the title below:

Table 1. The Result of Pretest and Posttest

\begin{tabular}{cccc}
\hline No & Name & Pretest & Postest \\
\hline $\mathbf{1}$ & Student 1 & 35 & 75 \\
\hline $\mathbf{2}$ & Student 2 & 46 & 85 \\
\hline $\mathbf{3}$ & Student 3 & 55 & 80 \\
\hline $\mathbf{4}$ & Student 4 & 60 & 85 \\
\hline $\mathbf{5}$ & Student 5 & 25 & 65 \\
\hline $\mathbf{6}$ & Student 6 & 40 & 70 \\
\hline $\mathbf{7}$ & Student 7 & 52 & 85 \\
\hline $\mathbf{8}$ & Student 8 & 35 & 70 \\
\hline $\mathbf{9}$ & Student 9 & 30 & 60 \\
\hline
\end{tabular}




\begin{tabular}{llll}
\hline $\mathbf{1 0}$ & Student 10 & 46 & 80 \\
\hline $\mathbf{1 1}$ & Student 11 & 36 & 75 \\
\hline $\mathbf{1 2}$ & Student 12 & 36 & 85 \\
\hline $\mathbf{1 3}$ & Student 13 & 30 & 80 \\
\hline $\mathbf{1 4}$ & Student 14 & 50 & 90 \\
\hline $\mathbf{1 5}$ & Student 15 & 45 & 80 \\
\hline $\mathbf{1 6}$ & Student 16 & 20 & 60 \\
\hline $\mathbf{1 7}$ & Student 17 & 35 & 75 \\
\hline $\mathbf{1 8}$ & Student 18 & 25 & 60 \\
\hline $\mathbf{1 9}$ & Student 19 & 30 & 70 \\
\hline $\mathbf{2 0}$ & Student 20 & 45 & 85 \\
\hline $\mathbf{2 1}$ & Student 21 & 55 & 75 \\
\hline $\mathbf{2 2}$ & Student 22 & 40 & 80 \\
\hline $\mathbf{2 3}$ & Student 23 & 55 & 85 \\
\hline $\mathbf{2 4}$ & Student 24 & 60 & 95 \\
\hline $\mathbf{2 5}$ & Student 25 & 60 & 75 \\
\hline $\mathbf{2 6}$ & Student 26 & 35 & 85 \\
\hline $\mathbf{2 7}$ & Student 27 & 50 & 80 \\
\hline $\mathbf{2 8}$ & Student 28 & 35 & 75 \\
\hline $\mathbf{2 9}$ & Student 29 & 20 & 70 \\
\hline $\mathbf{3 0}$ & Student 30 & 60 & 90 \\
\hline & & & \\
\hline
\end{tabular}

The table 1 shows that the mean of pre test was 41,53, the mean of post test was 77,50, the maximum score of pretest was 60 , the maximum score of post test was 95 , The minimum score of pretest was 20, The minimum score of post test was 60 . Then the researchers continued to analyze the data using SPSS.

Here is test normality

Table 2. Tests of Normality

\begin{tabular}{cccccccc}
\hline & & \multicolumn{4}{c}{ Kolmogorov-Smirnova $^{\mathrm{a}}$} & & \multicolumn{3}{c}{ Shapiro-Wilk } \\
\cline { 3 - 8 } & Score & Statistic & Df & Sig. & Statistic & Df & Sig. \\
\hline \multirow{2}{*}{ Class } & Pretest & .140 & 30 & .135 & .945 & 30 & .122 \\
\cline { 2 - 8 } & Posttest & .142 & 30 & .127 & .948 & 30 & .146 \\
\hline
\end{tabular}

The table shows that the Sig. level of pre test was 0,135 and post test was 0,127 . The data were higher than 0,05 , so the data were normal. So the researchers continued to analyze paired sample test. 
Table 3. Paired Samples Test

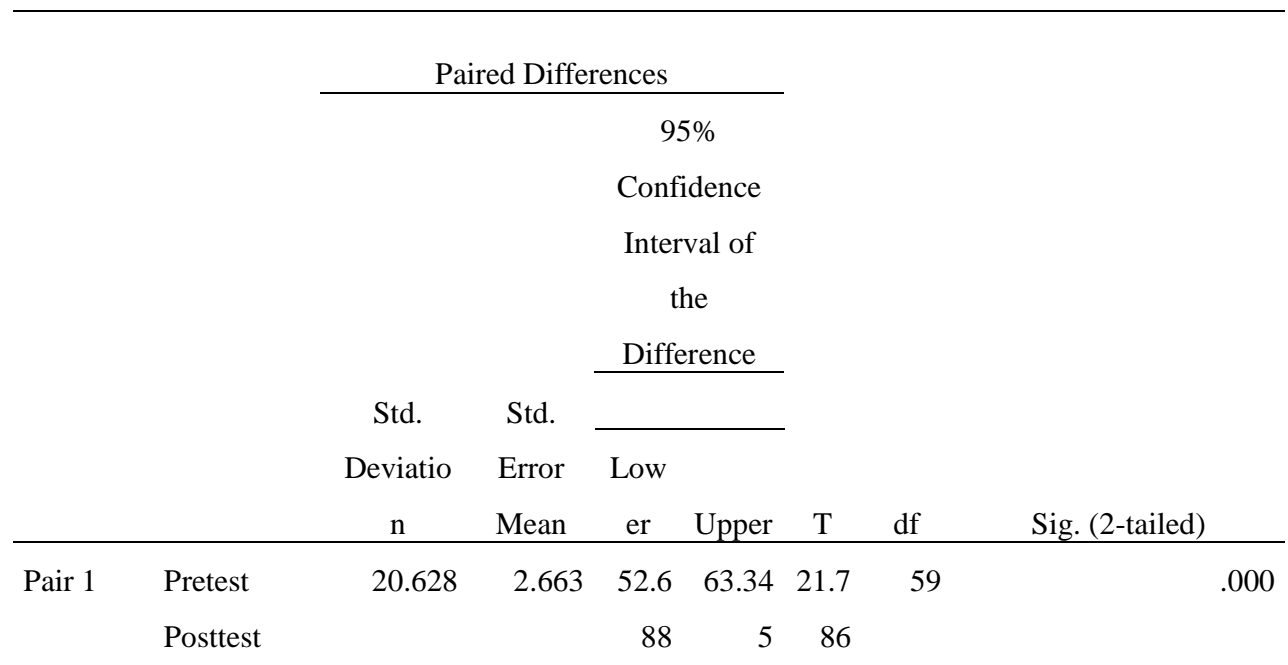

The table shows that, the result Sig. was $0.000<0.005$ so, the null hypothesis was rejected and the alternative hypothesis was accepted. It means word game is effective to teach vocabulary.

\section{Discussion}

Based on the data statistics above, the result of this research show that the improvement of students' vocabulary mastery could be seen in the increasing of mean score of pretest 41.53 and the mean of posttest 77.50. The last, the result Sig. $0.000<0.005$. So, the alternative hypothesis was accepted and the null hypothesis was rejected. It means there were improvement of the score after using word game method at the seventh-grade students of SMP Muslimin Cililin.

\section{CONCLUSION}

The data show that the use of word games have contributed to the improvement of performance since at the pretest and the word game is able to enhance the students' vocabulary. Based on the result the researchers concluded that the use of word game is effective to enhance students vocabulary in seventh-grade of SMP Muslimin Cililin.

\section{ACKNOWLEDGMENTS}

We would like to thank to my lord Allah SWT, All Praise be to Allah SWT who has allowed the researchers to finish this paper. Peace and salutation for Rasulullah SAW. And also Thanks 
to Our parents, Our family and Our lectures during doing the paper the researchers get many help, motivations, and suggestions.

\section{REFERENCES}

Apsari, Y. (2018). Snowball Throwing in Teaching Grammar. Lingual, 10(1), 52-59.

D, Bonet. 1992. Vocabulary Improvement Words Made Easy. United State: Course Ptr.

Jeremy Harmer. 2001. The Practice Of English Language Teaching. Longman: Essex England. Parmawati, A. Using Magic Sentences Technique To Improve Students'vocabulary (Classroom

Action Research In The First Semester Students Of Ikip Siliwangi Bandung).

S, Sugar \& K, Sugar. 2002. "Primary Games : Experiential Leraning Activities."

Sanchez, Morfin \& Campos. 2007. "Interactive Games In The Teaching Learning Process Of A Foreign Language."

Suryani, Lilis. 2015. “The Effectiveness Of Role Play In Teaching Speaking.” Journal. Eltin Journal 3(11): 106.

Thornbury, S. 2002. How To Teach Vocabulary. Uk: Longman. 